\title{
Water quality assessment of carbonate aquifers in southern Latium region, Central Italy: a case study for irrigation and drinking purposes
}

\author{
Giuseppe Sappa $\cdot$ Sibel Ergul $\cdot$ Flavia Ferranti
}

Received: 27 February 2013/ Accepted: 11 October 2013/Published online: 24 October 2013

(C) The Author(s) 2013. This article is published with open access at Springerlink.com

\begin{abstract}
In southern Latium region, Central Italy, groundwater and spring water resources in the carbonate aquifers are the major contributors of drinking and irrigation water supply. The aim of this study was to review hydrochemical processes that control the groundwater chemistry and to determine the suitability of springs and groundwater for irrigation and drinking purposes on the basis of the water quality indices. Physical $(\mathrm{pH}$, electrical conductivity, total dissolved solids) and hydrochemical characteristics $\left(\mathrm{Na}^{+}, \mathrm{K}^{+}, \mathrm{Ca}^{2+}, \mathrm{Mg}^{2+}, \mathrm{HCO}_{3}^{-}, \mathrm{Cl}^{-}\right.$, and $\mathrm{SO}_{4}{ }^{-}$) of springs and groundwater were determined. To assess the water quality, chemical parameters like sodium adsorption ratio (SAR), total hardness, Mg-hazard (MH), sodium percentage (Na \%), salinity hazard, permeability index, and Kelly's ratio were calculated based on the analytical results. A Durov diagram plot revealed that the groundwater has been evolved from $\mathrm{Ca}$ to $\mathrm{HCO}_{3}$ recharge water, followed by mixing and reverse ion exchange processes, due to the respective dominance of $\mathrm{Na}-\mathrm{Cl}$ and $\mathrm{Ca}-$ $\mathrm{Cl}$ water types. According to Gibbs's diagram plots, chemical weathering of rock forming minerals is the major driving force controlling water chemistry in this area. Groundwater and spring samples were grouped into six categories according to irrigation water quality assessment diagram of US Salinity Laboratory classification and most of the water samples distributed in category $\mathrm{C} 2-\mathrm{S} 1$ and
\end{abstract}

G. Sappa $(\bowtie) \cdot$ S. Ergul

Dipartimento di Ingegneria Civile, Edile e Ambientale, Sapienza Università di Roma, Rome, Italy

e-mail: giuseppe.sappa@uniroma1.it

F. Ferranti

Centro Reatino di ricerche di Ingegneria per la Tutela e la Valorizzazione dell'Ambiente e del Territorio, SapienzaUniversità di Roma, Rieti, Italy
C3-S1 highlighting medium to high salinity hazard and low sodium content class. The results of hydrochemical analyses and the calculated water quality parameters suggest that most of the water samples are suitable for irrigation and drinking purposes, except for the samples influenced by seawater and enhanced water-rock interaction. High values of salinity, $\mathrm{Na} \%, \mathrm{SAR}$, and $\mathrm{MH}$ at certain sites, restrict the suitability for agricultural uses.

Keywords Carbonate aquifers - Geochemical characteristics - Water quality parameters - Salinity . Water-rock interaction

\section{Introduction}

Groundwater is an important natural resource especially for drinking and irrigation uses. Water quality assessment is essential for human health and the definition of water quality depends on the desired use of water (Hoek et al. 2001; Jain et al. 2009; Kirda 1997). Therefore, different uses require different criteria of water quality as well as standard methods for reporting and comparing results of water analysis (Singh et al. 2004). The natural water analyses for physico-chemical properties are very important for public health studies (Rizwan and Singh 2009). These studies are also a main part of pollution studies in the environment (Palma et al. 2010). The variations of water quality are essentially the combination of both anthropogenic and natural contributions (Chen et al. 2006). Natural variations in groundwater hydrochemistry should be considered when assessing water quality data from groundwater monitoring programmes, as elevated concentrations for certain parameters might be influenced by the aquifer lithology (Kumar et al. 2009). Therefore, to ensure that long-term sustainable groundwater 
resources are achieved, groundwater resource management is required through an assessment of anthropogenic pressures and the physical characteristics of the subsurface deposits, i.e. soil, subsoil, and aquifer type. The water quality assessment is mostly based on hydrochemical analysis and many organizations renew and publish the guidelines for drinking water to protect public health.

In Italy, water for different uses (i.e. drinking and agricultural) relies mostly on groundwater resources from carbonate aquifers. Carbonate aquifer systems often respond rapidly to changes in environmental and climatic conditions (Mahler and Massei 2007). Many studies have been conducted on carbonate aquifer systems such as geochemical processes in these systems and their hydrogeological implications. In these systems, chemical composition of groundwater is controlled by many factors, including the composition of the precipitation, variations in flow, seasonal changes in recharge, geological structure, and mineralogy of the aquifers (Chenini and Khmiri 2009). The interaction of all factors leads to various water types. In recent years, hydrochemical investigation techniques provide much information for the identification of main hydrogeochemical processes affecting the composition and the quality of spring and groundwater within the carbonate aquifers (Briz-Kishore and Murali 1992). The hydrochemical properties are generally related to (1) water-rock interactions, (2) natural factors such as mixing between seawater and freshwater, (3) anthropogenic factors, and (4) the type of groundwater circulation (Mercado and Billings 1975; Mayer 1999). On the other hand, the composition of water in carbonate systems is the result of the dissolution of variable quantities of rock forming minerals that controls the water chemistry (White 1988; Ettazarini 2005; Edmunds et al. 1987; Moral et al. 2008).

In the present work, spring waters and groundwater from the carbonate aquifers of the southern Latium region were characterized employing physico-chemical data to determine the water suitability for different uses (i.e. drinking and irrigation). This study was also designed to hydrochemically characterize these aquifer systems, with the aim of achieving proper management and protection of these important resources. The main objectives of this study are (1) evaluation of water geochemistry; (2) determination of water quality parameters; and (3) assessment of water suitability for drinking and irrigation purposes by comparing the identified parameters with the standards and guidelines.

\section{Methodology}

The main spring water and groundwater sampling survey was carried out in southern Latium region of Central Italy from 2002 to 2006. Groundwater samples were collected from 20 wells in Pontina Plain and 54 spring water samples were collected from Lepini (12 springs), Ausoni (16 springs), and Aurunci (26 springs) mountains (Fig. 1). All samples were collected in laboratory certified clean bottles and location; date and time of sample collection were recorded. Water temperature, electrical conductivity, and $\mathrm{pH}$ values were determined in the field using PC 300 Waterproof Hand-held meter (http://www.eutechinst.com/ manuals/english/pc300_r3.pdf). Laboratory analyses included major cations and anions. All samples were maintained in refrigerated conditions before analyses. For chemical analysis, $250 \mathrm{ml}$ of water was collected in polyethylene bottles, filtered and then acidified (http://www.irsa.cnr.it/ ShPage.php?lang=en\&pag=nma). Water samples were filtered through cellulose filters $(0.45 \mu \mathrm{m})$, and their major and minor constituents were determined by a Metrohm 761 Compact IC ion chromatograph (replicability $\pm 2 \%$ ) (http://www.metrohm.it/Produkte2/IC/index.html). A Metropes C2-100 column was used to determine cations $\left(\mathrm{Na}^{+}\right.$, $\mathrm{K}^{+}, \mathrm{Mg}^{2+}, \mathrm{Ca}^{2+}$ ), while a Metropes A Supp 4-250 column was used for anions $\left(\mathrm{Cl}^{-}, \mathrm{SO}_{4}{ }^{-}, \mathrm{HCO}_{3}{ }^{-}\right)$(Metrohm 2000) The analytical accuracy of these methods ranged from 2 to $5 \%$. Bicarbonate content was measured by titration with $0.1 \mathrm{~N} \mathrm{HCl}$ using colour turning method with methyl orange as indicator. Chemical analyses were performed on the collected water samples at the Geochemical Laboratory of Sapienza, "University of Rome". The characterization of spring and groundwater samples has been evaluated by means of major ions, $\mathrm{Ca}^{2+}, \mathrm{Mg}^{2+}, \mathrm{HCO}_{3}{ }^{-}, \mathrm{Na}^{+}, \mathrm{K}^{+}, \mathrm{Cl}^{-}$ and $\mathrm{SO}_{4}{ }^{-}$. For the identification of water types, the chemical analysis data of the spring water samples have been plotted on the Piper and Durov diagrams using Geochemistry Software AqQA, version AQC10664 (Rockware AqQA Software 2011). In addition, for the evaluation of water quality parameters magnesium and salinity hazard, sodium adsorption ratio (SAR), sodium percentage $(\mathrm{Na} \%)$, total hardness (as $\mathrm{CaCO}_{3}$ ), exchangeable sodium ratio (ESR), Kelly's ratio (KR), permeability index (PI), values of springs and groundwater samples were also determined using AqQA software and some mathematical calculations.

\section{Geology and hydrogeology}

Lepini, Ausoni and Aurunci are three different groups of mountains belonging to the pre-Apennines of Latium and they occupy a well-defined geographic area, called "Volscian mountain range" (Fig. 1). The Lepini Mountains are located in the northern part of Pontina Plain and hosts an important karst aquifer. The aquifer in the Lepini massif may be classified as "unconfined with an undefined bottom surface". The Pontina is a coastal plain developed along an extensional marine boundary and positioned between the Lepini-Ausoni mountains of the Central Apennines and the 
Tyrrhenian Sea (Fig. 1). In Pontina Plain, much of the groundwater comes out in springs near the boundary between the Pontina Plain and the carbonate massif, all of which join a series of streams and canals that drain to the Tyrrhenian Sea (Memon et al. 2011). Two aquifers are present in Pontina Plain: one is an unconfined aquifer lying under the Quaternary deposits covering the limestones at the south-western margin of the Lepini complex, and the second one is a confined aquifer where the water is discharged from the calcareous aquifer of the Lepini massif and flows to the sea. The Ausoni Mountains rise in southern Latium and extend to the coastline, starting immediately after the middle Amaseno valley (Fig. 1). The Ausoni hydrogeological unit is mainly composed of limestones with interbedded dolomitic limestones. Most of the springs lie along all of its borders but with no sharp separations between their recharge areas. The Aurunci Mountains represent the southeastern part of the Volscian range and are oriented more or less parallel to the Apennine range. The Aurunci Mountains are made of two distinct hydrogeological units: the western Aurunci, belonging to the Ausoni-Aurunci system, and the eastern Aurunci, which is separated from the western ones by a marly-arenaceous flysch complex (Boni 1975). The western Aurunci hydrogeological unit consists of dolomitic limestones and dolomites of Jurassic and Cretaceous age. The springs are supplied by groundwater that is derived from these geological formations. The groundwater is directly discharged into the Liri river through the narrow alluvial belt separating the unit from the river. The unit holds multiple hydrogeological basins, whose boundaries match important tectonic lines that caused the outcropping of the calcareous-dolomitic Jura (Accordi et al. 1976). The eastern Aurunci hydrogeological carbonate structure is surrounded by relatively less-permeable sediments, including the Frosinone flysch, the Roccamonfina volcanites and the Garigliano plain alluvia (Celico 1978).

\section{Results and discussion}

\section{Water chemistry}

Statistical summary of physical and hydrochemical parameters of sampled waters and guideline values of World Health Organization (WHO), US Environmental Protection Agency (US-EPA) and US Salinity Laboratory (USSL) for comparison are presented in Table 1. The temperature of Lepini springs range from 10 to $15^{\circ} \mathrm{C}$. The $\mathrm{pH}$ of these springs ranges from 6.9 to 8.1. Lepini springs show a total dissolved solids (TDS) content within the range $101.5-1,264.3 \mathrm{mg} / \mathrm{l}$. The electrical conductivity (EC) value of the springs varies from 138 to $1,540 \mu \mathrm{s} / \mathrm{cm}$. The temperature of Ausoni springs ranges from 12 to $15^{\circ} \mathrm{C}$. The $\mathrm{pH}$ of the Ausoni springs ranges from 7.1 to 8 indicating alkaline nature of the water. The EC and TDS values of the springs range from 315 to $2,310 \mu \mathrm{s} / \mathrm{cm}$ and 255.3 to 1,318.4 mg/l, respectively. The temperature of Aurunci springs ranges from 3 to $31^{\circ} \mathrm{C}$, with minimum and maximum values, respectively. The TDS content ranges from 245.6 to $1,149.7 \mathrm{mg} / \mathrm{l}$. Aurunci springs show alkaline nature $(\mathrm{pH} \mathrm{7.2-8.2)} \mathrm{with} \mathrm{low} \mathrm{to} \mathrm{medium} \mathrm{electrical} \mathrm{conduc-}$ tivity. However, few springs show high total dissolved solids $(1,150 \mathrm{mg} / \mathrm{l})$ and electrical conductivity $(1,217 \mu \mathrm{s} /$ $\mathrm{cm})$. This fact is probably related to the more time for water to interact with the host rock. The groundwater of Pontina Plain show alkaline character with $\mathrm{pH}$ values ranging from 7.3 to 8.0 corresponding to carbonate system waters. The temperature of groundwater ranges between 12 and $17.6{ }^{\circ} \mathrm{C}$. The electrical conductivity and TDS concentrations of the groundwater samples from Pontina Plain show varieties due to water rock interaction and seawater intrusion near the coastal area. The TDS and EC values of groundwater vary from 336 to $2,790.1 \mathrm{mg} / \mathrm{l}$ and 412 to 4,180 $\mu \mathrm{s} / \mathrm{cm}$, respectively (Sappa et al. 2012).

The conventional classification techniques (i.e. Piper and Durov diagrams) were applied to evaluate geochemical processes. The hydrochemical facies of springs and groundwater was studied by plotting the concentrations of major cations and anions in the Piper trilinear diagram (Sappa et al. 2012). The types of water that predominates in the study area are (1) $\mathrm{Ca}-\mathrm{Mg}-\mathrm{HCO}_{3}$; (2) mixed facies between $\mathrm{Ca}-\mathrm{HCO}_{3}$ and $\mathrm{Na}-\mathrm{Cl}$; (3) $\mathrm{Na}-\mathrm{Cl}$; (4) $\mathrm{Ca}-\mathrm{Cl}$ (Fig. 2). The major cation and anion concentrations of the samples from springs and groundwater in the region are plotted on a Durov diagram in Fig. 3. Durov's diagram helps the interpretation of the evolutionary trends and the hydrochemical processes occurring in the groundwater system and can indicate mixing of different water types, ion exchange and reverse ion exchange processes. In Fig. 3, samples fall in field 3 the zone of low-salinity water $\left(\mathrm{Ca}-\mathrm{Mg}-\mathrm{HCO}_{3}\right.$ recharge water); samples located in fields $5,6,7$ and 1 of Durov diagram indicate mixing and reverse ion exchange processes, respectively (the dominance of $\mathrm{Na}-\mathrm{Cl}$ and $\mathrm{Ca}-\mathrm{Cl}$ water types). Reverse ion exchange consists of exchange $\mathrm{Ca}^{2+}$ from the clay fraction in aquifer system. In the higher salinity environment, the process of reverse ion exchange may create $\mathrm{CaCl}_{2}$ waters due to the removal of $\mathrm{Na}^{+}$out of solution for bound $\mathrm{Ca}^{2+}$. Alternatively, $\mathrm{CaCl}_{2}$ type waters could also be a result of the mixing process between fresher water with more saline older water (Adams et al. 2001).

The major cations of springs and groundwater dominated by calcium and bicarbonate belong to the group of $\mathrm{Ca}-\mathrm{HCO}_{3}$ water type, followed by magnesium, sodium, sulphate and chloride. However, the composition of spring 
Table 1 Descriptive statistics of spring water and groundwater hydrochemistry and guideline values of WHO, US-EPA and USSL

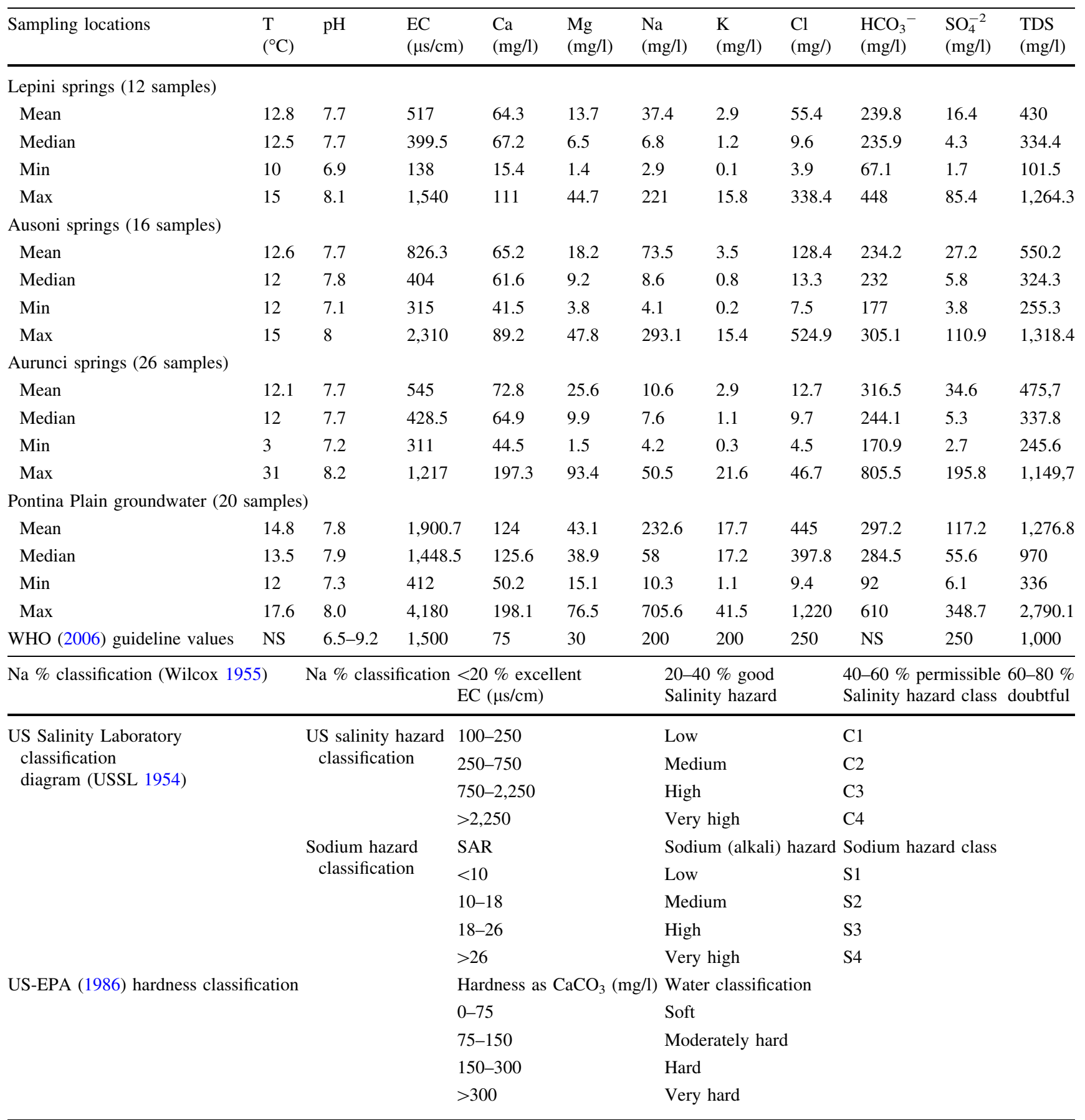

NS not stated

samples discharge at lower elevations, issuing from Lepini and Ausoni Mountains, and groundwater from Pontina Plain belong to or show a tendency to the group of $\mathrm{Na}-\mathrm{Cl}$ dominated by chloride, sodium, sulphate and potassium. The large variations in ion concentrations, TDS and electrical conductivity (EC) were thought to be mainly due to water-rock interaction along the flow paths and seawater intrusion in the coastal area. In the previous studies, this fact was studied by geochemical modeling and saturation index computation of the Lepini, Ausoni and Aurunci springs and Pontina Plain groundwater. The results of geochemical modeling suggest that most of the spring water and groundwater samples are saturated with respect to calcite and dolomite; however, all sampled waters are undersaturated with respect to gypsum and halite (Sappa et al. 2012). The Gibbs plots are employed to understand 


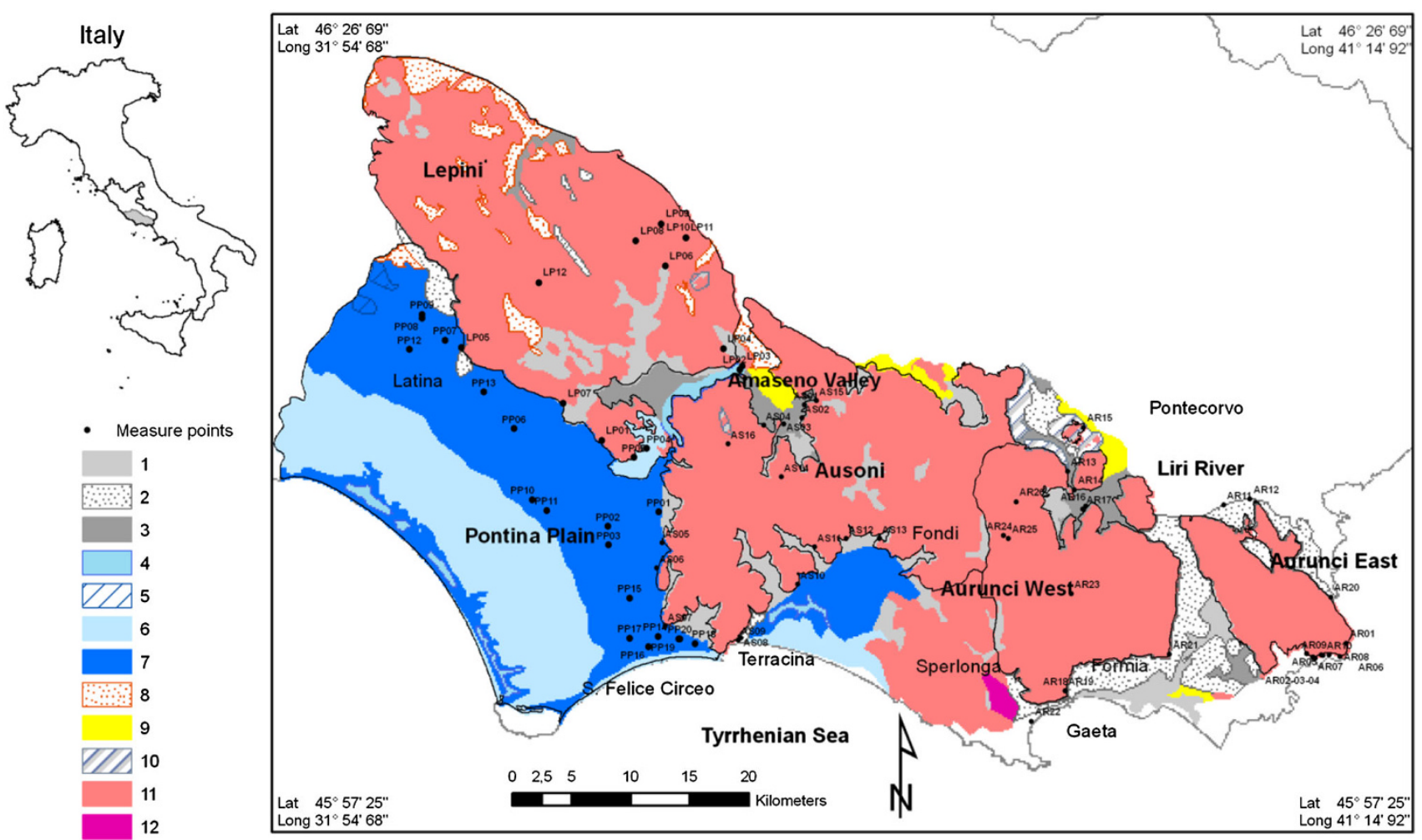

Fig. 1 Simplified hydro-geological map of the study area

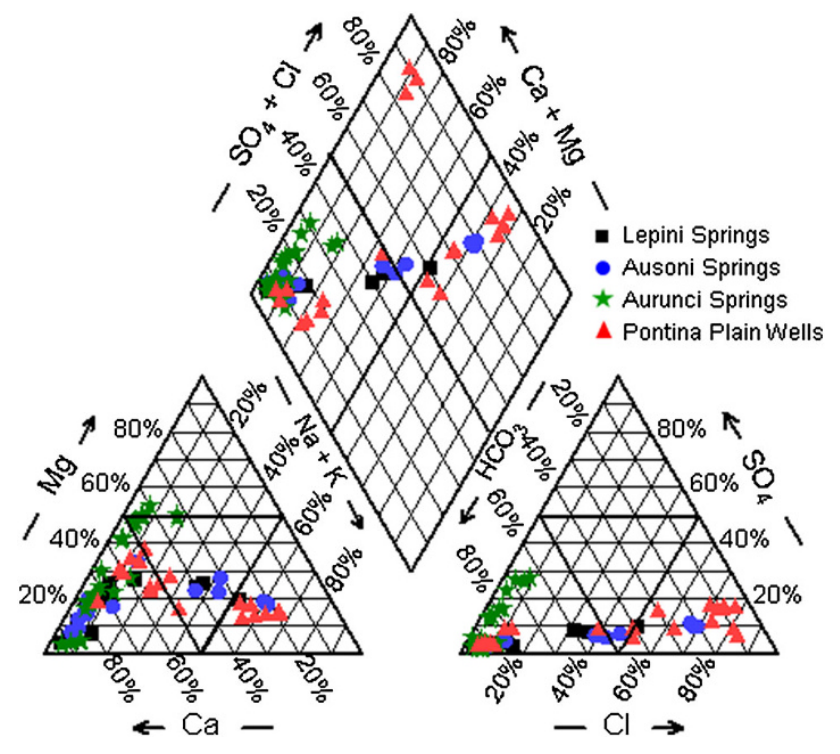

Fig. 2 Piper diagram of springs and groundwater samples

the processes which affect the geochemical parameters of springs and groundwater. These diagrams, representing the plot of $\log (\mathrm{TDS})$ versus ratios of $\mathrm{Na}^{+} /\left(\mathrm{Na}^{+}+\mathrm{Ca}^{2+}\right)$ and $\mathrm{Cl}^{-} /\left(\mathrm{Cl}^{-}+\mathrm{HCO}_{3}{ }^{-}\right)$, are widely used to assess the distinction between waters controlled by water-rock interaction (i.e. leaching and dissolution), evaporation and precipitation (Gibbs 1970). Gibbs's plots (Fig. 4) show that most spring and groundwater samples fall in the rock dominance area. The water-rock interaction (chemical weathering of rock forming minerals) predominates the water chemistry of these springs and groundwater. However, some spring (low discharge Lepini and Ausoni springs) and groundwater samples clustered in the region of evaporation zone. Evaporation increases salinity by increasing $\mathrm{Na}^{+}$and $\mathrm{Cl}^{-}$with relation to increase of TDS. This is also observed by Piper plot, having significant increase of $\mathrm{Na}^{+}$and $\mathrm{Cl}^{-}$in some spring and groundwater samples. This may be attributed to the dissolution of evaporate minerals (such as halite) and seawater intrusion near the coastal area.

\section{Water quality assessment}

The chemical parameters play an important role in classifying and assessing water quality. Thus, to evaluate water quality for different uses, water quality indices such as TDS, EC, pH, SAR, Mg-hazard (MH), total hardness, salinity hazard, ESR, permeability index, Kelly's ratio and sodium percentage were calculated from the chemical analyses of 54 spring and 20 groundwater samples. The results of the different indices for irrigation water quality are presented in Table 2 . Then, the analytical results of 
Fig. 3 Durov's diagram of springs and wells for definition of groundwater chemical types

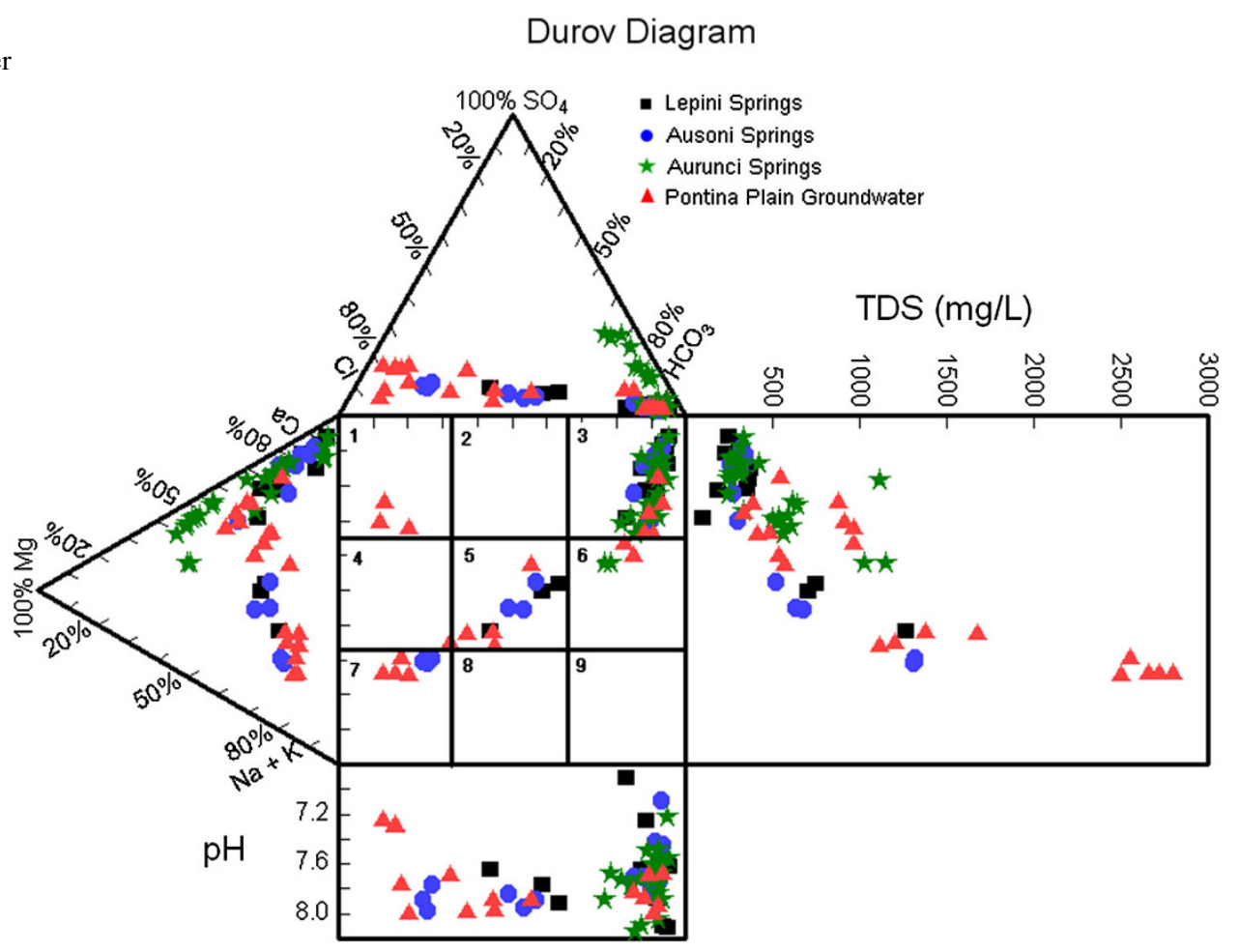

physical and chemical parameters of springs and groundwater were compared with the standard guideline values.

\section{Drinking water quality}

Major anions and cations The concentration of various ions in the groundwater and spring samples was compared with WHO standards, which are given in Table 1. The minimum required amounts of magnesium and calcium in drinking water are 10 and $20 \mathrm{mg} / \mathrm{l}$, respectively, and the desired amounts of magnesium and calcium in drinking water are 30-50 and 40-75 mg/l, respectively. The calcium concentrations in water samples range from 15.4 to $198.1 \mathrm{mg} / \mathrm{l}$ with minimum and maximum values, respectively. Almost $42 \%$ of the spring and groundwater samples contain Ca concentrations higher than $75 \mathrm{mg} / \mathrm{l}$, while about $3 \%$ of the springs show $\mathrm{Ca}$ concentrations less than $40 \mathrm{mg} / \mathrm{l}$. Besides, $55 \%$ of the total samples show $\mathrm{Ca}$ concentrations ranging between 40 and $75 \mathrm{mg} / \mathrm{l}$. In the study area, magnesium concentrations range between 1.4 and $93.4 \mathrm{mg} / \mathrm{l}$. Most of the samples $(\sim 60 \%)$ show magnesium concentrations $<30 \mathrm{mg} / \mathrm{l}$. However, about $17.5 \%$ of 74 samples show magnesium concentrations higher than $50 \mathrm{mg} / \mathrm{l}$. The remaining water samples have magnesium concentrations within the range of $30-50 \mathrm{mg} / \mathrm{l}$. Among the springs, the highest calcium $(197.3 \mathrm{mg} / \mathrm{l})$ and magnesium (93.4 mg/l) concentrations were observed in water samples from Aurunci mountains. Besides, groundwater samples from Pontina Plain also show higher Ca (198.1 mg/l) and
Mg (76.5 mg/l) concentrations. The sulphate concentration in water samples ranged from 1.7 to $348.7 \mathrm{mg} / \mathrm{l}$. The highest values were observed in Aurunci springs (195.8 mg/l) and Pontina Plain (348.7 mg/l) groundwater; however, most of the samples are within the maximum allowable limits WHO (2006) standards. The high concentration of sulphate is likely due to the dissolution of gypsum minerals which is common in the study area. Nevertheless, high concentrations of sulphate in groundwater of Pontina Plain are attributed to the proximity of the sampling locations to the coast. Bicarbonate values in water samples vary from 67.1 to $805.5 \mathrm{mg} / \mathrm{l}$. The potassium values of the water samples range from 0.1 to $41.5 \mathrm{mg} / \mathrm{l}$ and most of the samples in the study area fall within the guideline levels; however, springs and groundwater belonging to $\mathrm{Mg}-\mathrm{HCO}_{3}$ and $\mathrm{Na}-\mathrm{Cl}$ water types show higher potassium concentrations. The sources of potassium in the water samples are attributed to the dissolution of silicate minerals, seawater intrusion near the coastal area and/or agricultural activities. Sodium and chloride concentrations in the investigated water samples are found in the range of 2.9-705.6 and 3.9-1,220 mg/1 with minimum and maximum values, respectively. The highest concentrations were observed in some groundwater samples of Pontina Plain and some low discharge springs from Lepini and Ausoni Mountains. Most of the samples have sodium and chloride levels are not in excess of the permissible limit of 200 and $250 \mathrm{mg} / \mathrm{l}$, respectively (WHO 2006). Based on these results and comparison values, most of the 

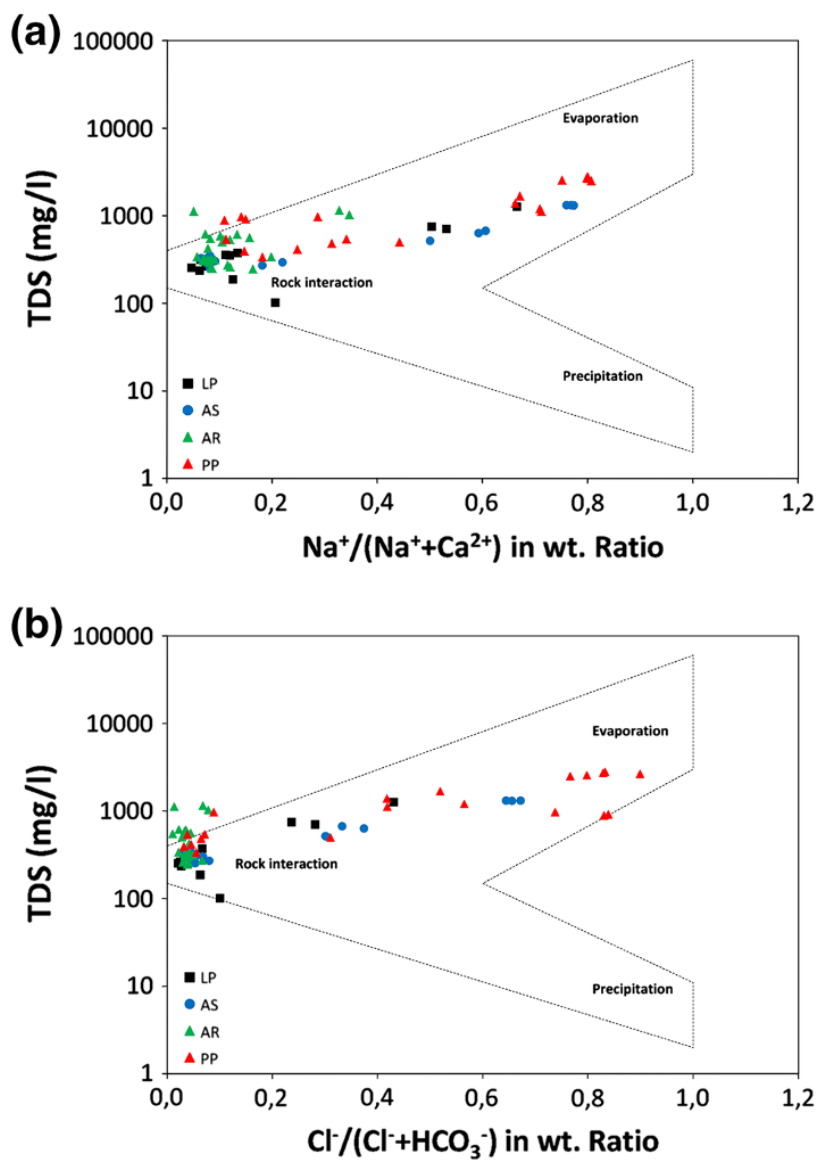

Fig. 4 Gibbs diagrams showing the mechanism controlling water chemistry. a Plot of $\log$ (TDS) versus $\left(\mathrm{Na}^{+}\right) /\left(\mathrm{Na}^{+}+\mathrm{Ca}^{2+}\right)$ and $\mathbf{b}$ plot of $\log$ TDS versus $\mathrm{Cl}^{-} /\left(\mathrm{Cl}^{-}+\mathrm{HCO}_{3}{ }^{-}\right)$

groundwater and spring samples were found to be within the suitable limits.

Total dissolved solids (TDS) High concentration of TDS in drinking water may cause adverse taste effects. A water containing TDS $<500 \mathrm{mg} / \mathrm{l}$ can be considered as fresh water. Water with a TDS lower than $1,000 \mathrm{mg} / \mathrm{l}$ is usually acceptable for consumers (WHO 2006). In the study area, the TDS content of spring water ranges from 101.5 to $1,318.4 \mathrm{mg} / \mathrm{l}$. It was found that $87 \%$ of the spring water samples are classified as fresh water, while the rest of the springs are considered as a brackish water according to the WHO guidelines. Most of the spring samples show TDS values below $1,000 \mathrm{mg} / \mathrm{l}$ and suitable for drinking and irrigation purposes. Groundwater samples from Pontina Plain show the highest TDS values ranging from 335.9 to $2,790.1 \mathrm{mg} / \mathrm{l}$. Based on WHO Guidelines for drinkingwater quality, $45 \%$ of total groundwater samples fall in brackish water category while, $55 \%$ of total samples classified as fresh water.

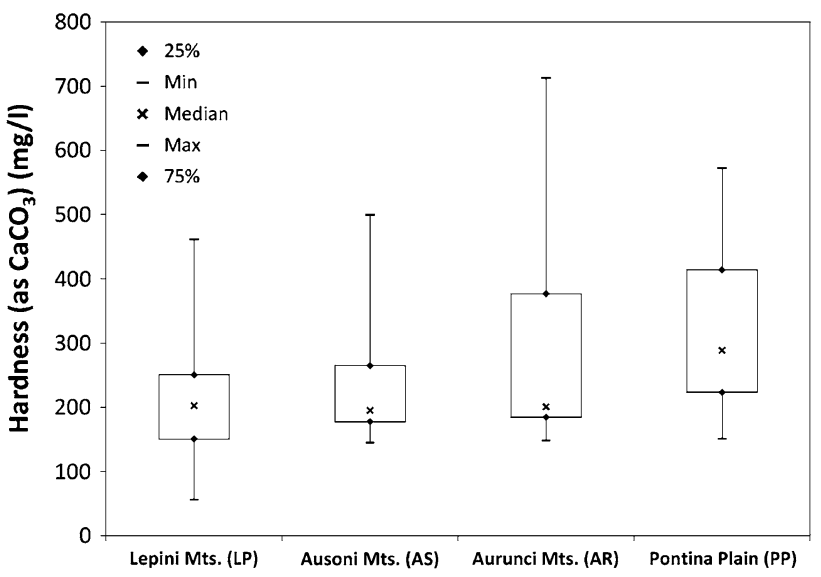

Fig. 5 Box plots show mean, median, 25-75 percentile, minimum and maximum values of total hardness

Hardness Determination of water hardness is a useful test to measure quality of water for domestic, agricultural and industrial uses. High levels of total hardness does not cause health risk; however, both extreme degrees very soft $\left(<75 \mathrm{mg} / \mathrm{l}\right.$ as $\left.\mathrm{CaCO}_{3}\right)$ and very hard $\left(>300 \mathrm{mg} / \mathrm{l}\right.$ as $\left.\mathrm{CaCO}_{3}\right)$ are considered as undesirable features in water. Hardness levels between 80 and $100 \mathrm{mg} / \mathrm{l}\left(\right.$ as $\mathrm{CaCO}_{3}$ ) are generally acceptable in drinking water and are considered tolerable by consumers (Ternan 1972; Bernardi et al. 1995; Memon et al. 2011). The total hardness of water is the sum of calcium and magnesium hardness expressed as $\mathrm{mg} / \mathrm{l}$ $\mathrm{CaCO}_{3}$. The total hardness (as $\mathrm{CaCO}_{3}$ ) of water samples can be calculated using the following equation (http:// water.usgs.gov/owq/hardness-alkalinity.html\#hardness):

$\left[\mathrm{CaCO}_{3}\right]=2.5\left[\mathrm{Ca}^{2+}\right]+4.1\left[\mathrm{Mg}^{2+}\right]$.

The US-EPA classified water that contains $0-75 \mathrm{mg} / \mathrm{l}$ $\mathrm{CaCO}_{3}$ as soft, $75-150 \mathrm{mg} / \mathrm{CaCO}_{3}$ as moderately hard, $150-300 \mathrm{mg} / \mathrm{l} \mathrm{CaCO}{ }_{3}$ as hard and $>300 \mathrm{mg} / 1 \mathrm{CaCO}_{3}$ as very hard (US-EPA 1986). The total hardness values (mean, median, maximum and minimum) of springs and groundwater were presented in Fig. 5. The total hardness of Lepini spring samples range from 56.2 to $461.2 \mathrm{mg} / \mathrm{l}$ (Table 2) and fall between soft and very hard water category. Ausoni spring water samples show total hardness ranging from 144.7 to $499.5 \mathrm{mg} / \mathrm{l}$ and classified as moderately hard to very hard water. The highest total hardness values were observed in water samples from Aurunci Mountains ranging from 148.2 to $712.7 \mathrm{mg} / \mathrm{l}$ with minimum and maximum values, respectively. Almost all Aurunci spring samples are characterized as very hard water. The classification of water based on total hardness shows that most of the spring water samples fall between hard and very hard water type. The total hardness values of groundwater from Pontina Plain range from 151 to $572.2 \mathrm{mg} / \mathrm{l}$ highlighting 
Table 2 Water quality parameters for springs and groundwater

\begin{tabular}{|c|c|c|c|c|c|c|c|c|c|}
\hline Samples & $\begin{array}{l}\text { Hardness (as } \\
\left.\mathrm{CaCO}_{3}\right)(\mathrm{mg} / \mathrm{l})\end{array}$ & Indication & $\begin{array}{l}\text { Salinity } \\
\text { hazard }\end{array}$ & Mg-hazard & $\begin{array}{l}\text { Na-adsorption } \\
\text { ratio (SAR) }\end{array}$ & $\begin{array}{l}\text { Exchangeable } \\
\text { Na ratio (ESR) }\end{array}$ & $\mathrm{Na} \%$ & $\begin{array}{l}\text { Kelly's } \\
\text { ratio (KR) }\end{array}$ & $\begin{array}{l}\text { Permeability } \\
\text { index }\end{array}$ \\
\hline LP01 & 318.6 & Very hard & High & 40.6 & 2.09 & 0.59 & 37.94 & 0.6 & 60.25 \\
\hline LP02 & 228.2 & Very hard & Medium & 27.6 & 0.26 & 0.09 & 8.38 & 0.1 & 48.47 \\
\hline LP03 & 221.7 & Very hard & Medium & 7.8 & 0.37 & 0.13 & 11.72 & 0.1 & 51.55 \\
\hline LP04 & 218.4 & Very hard & Medium & 22.0 & 0.25 & 0.09 & 8.28 & 0.1 & 50.86 \\
\hline LP05 & 461.2 & Soft & High & 39.9 & 4.48 & 1.04 & 52.08 & 1.0 & 65.44 \\
\hline LP06 & 157.8 & Hard & Medium & 17.2 & 0.15 & 0.06 & 5.69 & 0.1 & 58.66 \\
\hline LP07 & 348.4 & Very hard & High & 37.7 & 2.05 & 0.55 & 36.32 & 0.5 & 58.58 \\
\hline LP08 & 141.0 & Hard & Medium & 12.0 & 0.12 & 0.05 & 5.09 & 0.1 & 61.37 \\
\hline LP09 & 153.8 & Hard & Medium & 3.8 & 0.10 & 0.04 & 4.02 & 0.0 & 58.06 \\
\hline LP10 & 112.2 & Hard & Medium & 23.9 & 0.20 & 0.10 & 10.82 & 0.1 & 67.73 \\
\hline LP11 & 56.2 & Soft & Low & 31.5 & 0.23 & 0.16 & 15.91 & 0.2 & 94.35 \\
\hline LP12 & 186.4 & Very hard & Medium & 6.0 & 0.15 & 0.06 & 5.43 & 0.1 & 54.21 \\
\hline AS01 & 191.1 & Very hard & Medium & 19.6 & 0.16 & 0.06 & 5.92 & 0.1 & 53.69 \\
\hline AS02 & 188.0 & Very hard & Medium & 20.2 & 0.13 & 0.05 & 4.72 & 0.0 & 54.09 \\
\hline AS03 & 180.8 & Very hard & Medium & 14.9 & 0.20 & 0.08 & 7.25 & 0.1 & 54.43 \\
\hline AS04 & 144.7 & Hard & Medium & 19.1 & 0.38 & 0.16 & 13.99 & 0.2 & 65.33 \\
\hline AS05 & 238.4 & Very hard & Medium & 35.5 & 1.74 & 0.56 & 36.55 & 0.6 & 62.89 \\
\hline AS06 & 259.4 & Very hard & High & 39.5 & 2.47 & 0.77 & 44.09 & 0.8 & 66.05 \\
\hline AS07 & 419.7 & Very hard & Very high & 46.9 & 6.00 & 1.47 & 60.19 & 1.5 & 69.69 \\
\hline AS08 & 499.5 & Very hard & Very high & 46.6 & 6.35 & 1.59 & 61.95 & 1.6 & 71.53 \\
\hline AS09 & 407.9 & Very hard & Very high & 45.9 & 6.31 & 1.56 & 61.59 & 1.6 & 70.81 \\
\hline AS10 & 280.9 & Very hard & High & 46.9 & 2.38 & 0.71 & 42.20 & 0.7 & 64.85 \\
\hline AS11 & 157.7 & Hard & Medium & 16.3 & 0.16 & 0.07 & 6.30 & 0.1 & 56.85 \\
\hline AS12 & 167.1 & Hard & Medium & 18.8 & 0.16 & 0.06 & 6.02 & 0.1 & 56.30 \\
\hline AS13 & 167.5 & Hard & Medium & 38.1 & 0.39 & 0.15 & 13.71 & 0.2 & 61.04 \\
\hline AS14 & 199.3 & Very hard & Medium & 7.8 & 0.16 & 0.06 & 5.39 & 0.1 & 51.66 \\
\hline AS15 & 189.6 & Very hard & Medium & 12.6 & 0.15 & 0.05 & 5.36 & 0.1 & 53.33 \\
\hline AS16 & 211.7 & Very hard & Medium & 9.9 & 0.20 & 0.07 & 6.74 & 0.1 & 50.73 \\
\hline AR01 & 639.0 & Very hard & High & 60.2 & 0.85 & 0.17 & 17.51 & 0.2 & 36.17 \\
\hline AR02 & 332.3 & Very hard & Medium & 50.2 & 0.19 & 0.05 & 5.74 & 0.1 & 41.19 \\
\hline AR03 & 347.5 & Very hard & Medium & 52.9 & 0.21 & 0.06 & 6.42 & 0.1 & 35.79 \\
\hline AR04 & 381.4 & Very hard & Medium & 48.5 & 0.20 & 0.05 & 5.86 & 0.1 & 34.92 \\
\hline AR05 & 413.4 & Very hard & High & 43.8 & 0.18 & 0.04 & 7.53 & 0.1 & 52.89 \\
\hline AR06 & 326.1 & Very hard & Medium & 50.9 & 0.18 & 0.05 & 5.61 & 0.1 & 39.37 \\
\hline AR07 & 361.6 & Very hard & Medium & 57.3 & 0.26 & 0.07 & 7.43 & 0.1 & 37.93 \\
\hline AR08 & 585.4 & Very hard & High & 59.4 & 0.91 & 0.19 & 18.34 & 0.2 & 37.41 \\
\hline AR09 & 396.6 & Very hard & Medium & 42.9 & 0.16 & 0.04 & 4.37 & 0.0 & 35.43 \\
\hline AR10 & 388.7 & Very hard & Medium & 53.7 & 0.25 & 0.06 & 6.81 & 0.1 & 36.77 \\
\hline AR11 & 175.1 & Hard & Medium & 22.2 & 0.15 & 0.06 & 6.06 & 0.1 & 55.99 \\
\hline AR12 & 183.2 & Very hard & Medium & 31.6 & 0.40 & 0.15 & 14.04 & 0.1 & 60.47 \\
\hline AR13 & 194.4 & Very hard & Medium & 19.1 & 0.17 & 0.06 & 6.24 & 0.1 & 52.36 \\
\hline AR14 & 188.6 & Very hard & Medium & 19.2 & 0.15 & 0.05 & 5.47 & 0.1 & 52.87 \\
\hline AR15 & 252.2 & Very hard & Medium & 16.8 & 0.20 & 0.06 & 6.10 & 0.1 & 47.17 \\
\hline AR16 & 192.7 & Very hard & Medium & 19.7 & 0.15 & 0.05 & 5.52 & 0.1 & 53.14 \\
\hline AR17 & 202.5 & Very hard & Medium & 16.9 & 0.15 & 0.05 & 5.55 & 0.1 & 49.61 \\
\hline AR18 & 149.3 & Hard & Medium & 25.6 & 0.15 & 0.06 & 6.20 & 0.1 & 60.01 \\
\hline AR19 & 152.0 & Hard & Medium & 22.8 & 0.15 & 0.06 & 6.11 & 0.1 & 59.54 \\
\hline
\end{tabular}


Table 2 continued

\begin{tabular}{|c|c|c|c|c|c|c|c|c|c|}
\hline Samples & $\begin{array}{l}\text { Hardness (as } \\
\left.\mathrm{CaCO}_{3}\right)(\mathrm{mg} / \mathrm{l})\end{array}$ & Indication & $\begin{array}{l}\text { Salinity } \\
\text { hazard }\end{array}$ & Mg-hazard & $\begin{array}{l}\text { Na-adsorption } \\
\text { ratio (SAR) }\end{array}$ & $\begin{array}{l}\text { Exchangeable } \\
\text { Na ratio (ESR) }\end{array}$ & $\mathrm{Na} \%$ & $\begin{array}{l}\text { Kelly's } \\
\text { ratio (KR) }\end{array}$ & $\begin{array}{l}\text { Permeability } \\
\text { index }\end{array}$ \\
\hline AR20 & 712.7 & Very hard & High & 30.9 & 0.17 & 0.03 & 3.69 & 0.0 & 27.85 \\
\hline AR21 & 150.9 & Hard & Medium & 24.5 & 0.32 & 0.13 & 11.84 & 0.1 & 60.58 \\
\hline AR22 & 194.5 & Very hard & Medium & 22.0 & 0.19 & 0.07 & 6.68 & 0.1 & 52.11 \\
\hline AR23 & 148.2 & Hard & Medium & 5.0 & 0.28 & 0.11 & 10.37 & 0.1 & 62.71 \\
\hline AR24 & 158.7 & Hard & Medium & 4.6 & 0.27 & 0.11 & 9.97 & 0.1 & 59.05 \\
\hline AR25 & 188.4 & Very hard & Medium & 4.0 & 0.21 & 0.08 & 7.26 & 0.1 & 54.56 \\
\hline AR26 & 199.2 & Very hard & Medium & 3.2 & 0.15 & 0.05 & 5.06 & 0.1 & 52.68 \\
\hline PP01 & 251.8 & Hard & Medium & 28.5 & 0.9 & 0.3 & 22.85 & 0.3 & 58.13 \\
\hline PP02 & 337.5 & Very hard & High & 31.7 & 5.4 & 1.5 & 60.04 & 1.5 & 75.02 \\
\hline PP03 & 408.7 & Very hard & High & 38.7 & 5.3 & 1.3 & 56.91 & 1.3 & 68.73 \\
\hline PP04 & 201.5 & Hard & Medium & 37.8 & 0.3 & 0.1 & 11.26 & 0.1 & 54.26 \\
\hline PP05 & 312.0 & Very hard & Medium & 20.0 & 0.3 & 0.1 & 8.50 & 0.1 & 45.17 \\
\hline PP06 & 482.3 & Very hard & High & 36.9 & 4.7 & 1.1 & 53.57 & 1.1 & 66.53 \\
\hline PP07 & 263.9 & Hard & Medium & 36.9 & 9.2 & 0.3 & 26.46 & 0.3 & 57.31 \\
\hline PP08 & 213.4 & Hard & Medium & 29.6 & 5.9 & 0.2 & 22.49 & 0.2 & 58.82 \\
\hline PP09 & 218.6 & Hard & Medium & 31.8 & 3.0 & 0.1 & 11.12 & 0.1 & 54.26 \\
\hline PP10 & 151.3 & Hard & High & 37.6 & 5.0 & 0.1 & 14.26 & 0.1 & 16.97 \\
\hline PP11 & 151.0 & Hard & High & 32.9 & 3.8 & 0.1 & 9.84 & 0.1 & 15.03 \\
\hline PP12 & 428.2 & Very hard & High & 32.4 & 1.0 & 0.2 & 24.68 & 0.2 & 45.96 \\
\hline PP13 & 251.5 & Hard & High & 42.9 & 4.3 & 0.1 & 13.62 & 0.1 & 18.03 \\
\hline PP14 & 500.2 & Very hard & Very high & 43.9 & 10.5 & 2.1 & 67.58 & 2.0 & 72.58 \\
\hline PP15 & 572.2 & Very hard & Very high & 28.4 & 6.1 & 1.3 & 56.33 & 1.3 & 66.53 \\
\hline PP16 & 450.0 & Very hard & Very high & 36.3 & 9.3 & 1.7 & 63.06 & 1.7 & 67.75 \\
\hline PP17 & 265.5 & Hard & High & 23.9 & 1.7 & 0.5 & 35.03 & 0.5 & 57.59 \\
\hline PP18 & 400.0 & Very hard & Very high & 41.2 & 11.2 & 2.0 & 67.58 & 2.0 & 71.50 \\
\hline PP19 & 225.0 & Hard & Very high & 42.7 & 10.8 & 2.0 & 67.21 & 2.0 & 70.07 \\
\hline PP20 & 400.0 & Very hard & Very high & 41.1 & 11.0 & 2.0 & 67.57 & 2.0 & 71.52 \\
\hline
\end{tabular}

$L P$ Lepini springs, $A S$ Ausoni springs, $A R$ Aurunci springs, $P P$ Pontina Plain groundwater)

hard to very hard water category. Waters with hardness levels in excess of $200 \mathrm{mg} / \mathrm{l}$ are considered poor but have been tolerated by consumers; however, waters with hardness in excess of $500 \mathrm{mg} / \mathrm{l}$ are not suitable for most domestic purposes. Few spring and groundwater samples exceed the allowable limit for domestic uses. The observed high total hardness values in water samples are related to the main rock types in the area investigated, where limestone, dolomitic limestones and dolomites are the most dominant formations.

$p H$ values The $\mathrm{pH}$ values of spring samples range from 6.91 to 8.15 indicating slightly acidic to alkaline nature. According to the WHO (2004) guidelines, the range of desirable $\mathrm{pH}$ values for drinking water is 6.5-9.2. There are no spring and groundwater samples with $\mathrm{pH}$ values outside of the desirable ranges.
Suitability of water for irrigation purposes/irrigation water quality parameters

The results of the different irrigation indices sodium percentage, ESR, magnesium hazard, SAR, permeability index and Kelly's ratio for rating irrigation water quality are summarized in Table 2 and some comparison values are presented in Table 1 and discussed in the text.

Magnesium hazard (MH) Magnesium concentration of water plays an important role in determining the quality of water for irrigation purposes and hence, agricultural use. Magnesium hazard can be determined employing the following equation:

$\mathrm{MH}=\frac{\mathrm{Mg}^{2+}}{\mathrm{Ca}^{2+}+\mathrm{Mg}^{2+}} \times 100$. 


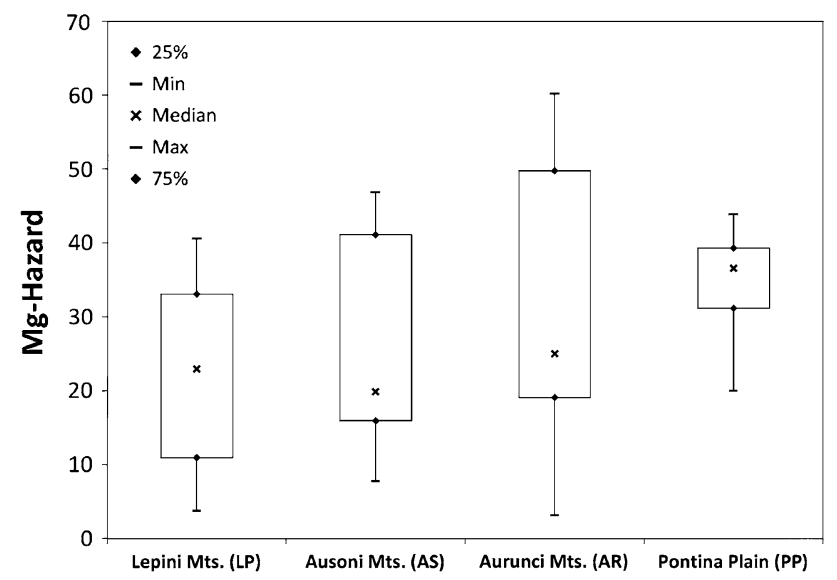

Fig. 6 Box plots show mean, median, 25-75 percentile, minimum and maximum values of magnesium hazard $(\mathrm{MH})$

Generally, magnesium hazard more than 50 is considered harmful and unsuitable for irrigation use (Szabolcs and Darab 1964). The high magnesium content in water will adversely affect crop yields as the soils become more saline (Joshi et al. 2009). Evaluation of mean, median, maximum and minimum values of magnesium hazard are depicted in box plots (Fig. 6). The magnesium hazard values of Lepini spring samples range from 3.8 to 40.6 indicating that they are within the acceptable limit. Similarly, the spring samples from Ausoni Mountains have also magnesium hazard values (7.8-46.9) $<50$ and can be classified as suitable for irrigation use. The magnesium hazard values of Pontina Plain groundwater are within the range 20-43.9 highlighting their suitability for irrigation. On the contrary, for Aurunci spring samples magnesium hazard values range from 3.2 to 60.2 (Table 2). It is found that $27 \%$ of spring samples from Aurunci Montains have magnesium hazard more than $50 \%$ indicating that they are unsuitable for irrigation.

Sodium adsorption ratio (SAR indicator) The SAR parameter evaluates the sodium hazard in relation to calcium and magnesium concentrations. This parameter is commonly used as an index to evaluate water suitability for irrigation purposes (Ayers and Westcot 1994; Shaki and Adeloye 2006). Thus, the suitability of the spring and groundwater samples was evaluated by determining the SAR. The SAR was calculated by the following equation (Richards 1954):

$\mathrm{SAR}=\frac{\mathrm{Na}}{\sqrt{(\mathrm{Ca}+\mathrm{Mg}) / 2}}$.

If SAR value is $<10$, the water is safe to irrigate with no structural deterioration. On the other hand, the SAR value is $>6-9$, the irrigation water will cause permeability problems on shrinking and swelling types of clayey soils (Saleh et al. 1999; FAO 1992). Continued use of water having high SAR leads to breakdown in the physical structure of the soil particles. High salt concentration in water leads to formation of saline soil and high sodium concentration leads to development of an alkaline soil (Singh et al. 2008). The SAR values of springs and groundwater samples are presented in Table 2. The SAR values of Lepini springs range from 0.10 to 4.48. Samples from Ausoni springs show higher SAR values, ranging from 0.13 to 6.35; however, they fall within the recommended limits. The highest SAR values were found in groundwater samples from Pontina Plain ranging from 0.3 to 11.2. SAR values of water samples from Aurunci springs range from 0.15 to 0.91 highlighting their suitability for irrigation purposes. SARs for spring water samples of the study area are $<10$ indicating excellent quality for irrigation and all the samples fall in excellent (S1) category. However, some groundwater samples from Pontina Plain having SAR value more than 10 are unsuitable for irrigation. To determine how the interaction of the various ions affect the suitability of the water for irrigation, the SAR has been plotted with the conductivity measurement on the classical USSL (1954) classification diagram in Fig. 7. US of salinity diagram uses SAR and EC values for classifying irrigation water quality. In this diagram, waters have been divided into low (C1), medium (C2), high (C3) and very high (C4) types on the basis of salinity hazard. On the basis of sodium hazard waters have been classified low (S1), medium (S2), high (S3) and very high (S4) types (USSL 1954). In the study area, electrical conductivity values show varieties. The electrical conductivity of sampled waters ranges between 138 and 4,180 $\mu \mathrm{s} / \mathrm{cm}$ with a minimum and maximum value, respectively. As seen in Fig. 7, most of the water samples fall in $\mathrm{C} 2-\mathrm{S} 1$ class highlighting medium salinity and low sodium content class. Only one sample sample falls in $\mathrm{C} 1-\mathrm{S} 1$ showing low salinity and sodium content class. However, some spring and groundwater samples fall in the field of $\mathrm{C} 3-\mathrm{S} 1$ and $\mathrm{C} 4-\mathrm{S} 2$, which indicates a high to very high salinity hazard and low to medium sodium content. On the contrary, most of the groundwater samples from Pontina Plain fall in the category C3-S1, C3-S2, C4S3 and C4-S2 with high to very high salinity and low to high sodium hazard. Water that falls in the medium salinity hazard class (C2) can be used in most cases without any special practices for salinity control. Water samples falling in the high salinity hazard class (C3) may have adverse effects on sensitive crops and plants; however, very high salinity water (C4) is not suitable for irrigation. In the study area, spring samples taken near the coast and groundwater samples from Pontina Plain show very high salinity hazard and are unsuitable for irrigation. 


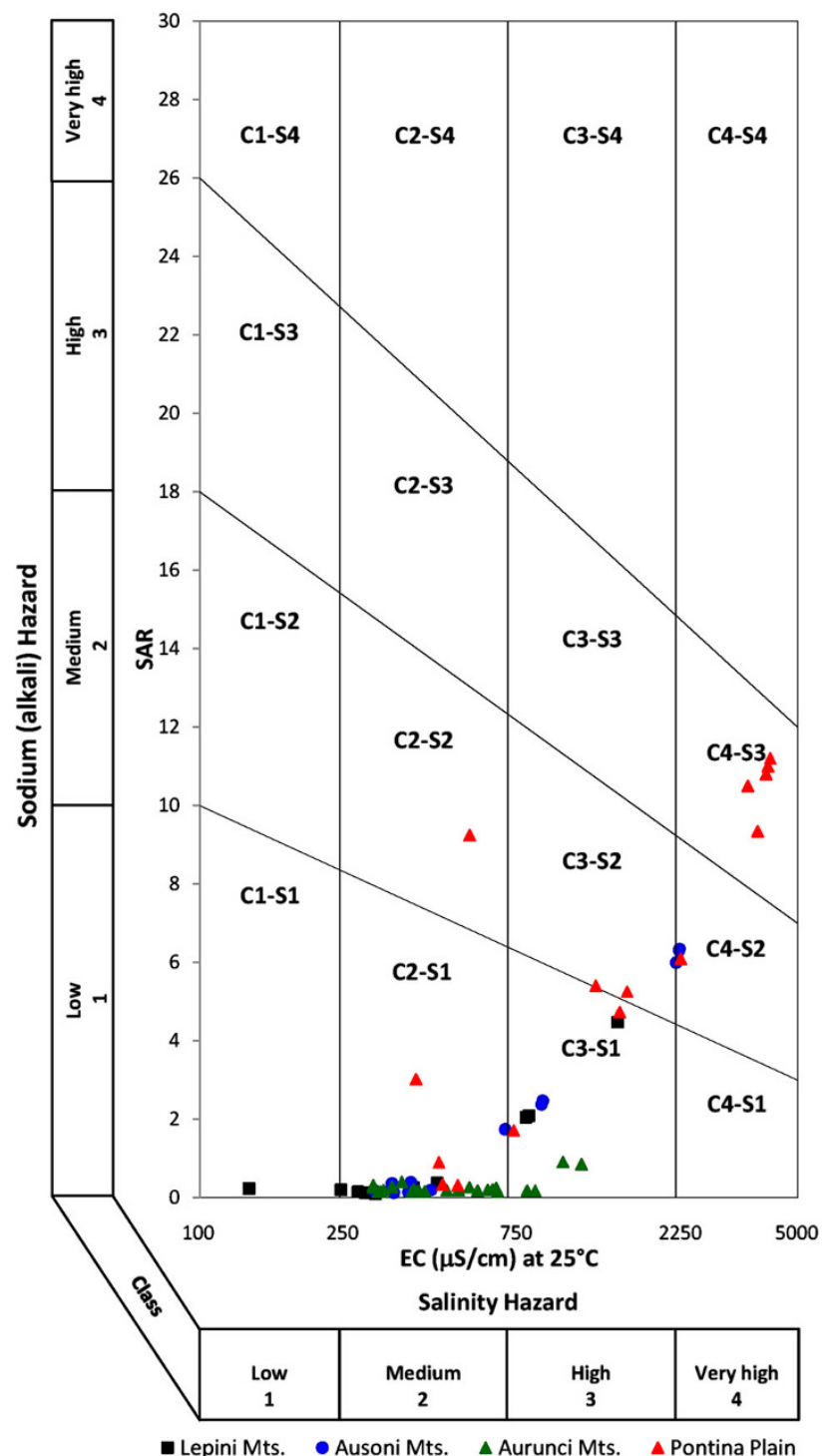

Fig. 7 US salinity classification of springs and groundwater for irrigation (after Richards 1954)

Permeability index (PI) Based on permeability index, Doneen (1964) classified the groundwater as Class I (>75 \%), Class II $(25-75 \%)$ and Class III $(<25 \%)$ to find out suitability of groundwater for irrigation purpose. Accordingly, Class I and Class II are categorized as good for irrigation, while Class III water are unsuitable for irrigation with $25 \%$ of maximum permeability. The permeability index was calculated employing the following equation, where all the ions are expressed in meq/l:

$\frac{\mathrm{Na}+\sqrt{\mathrm{HCO}_{3}}}{\mathrm{Ca}+\mathrm{Mg}+\mathrm{Na}} \times 100$.

The permeability index values range between 15.03 and 94.35 (Fig. 8). Most of the water samples fall in Class II and only two samples fall in Class I indicating good quality

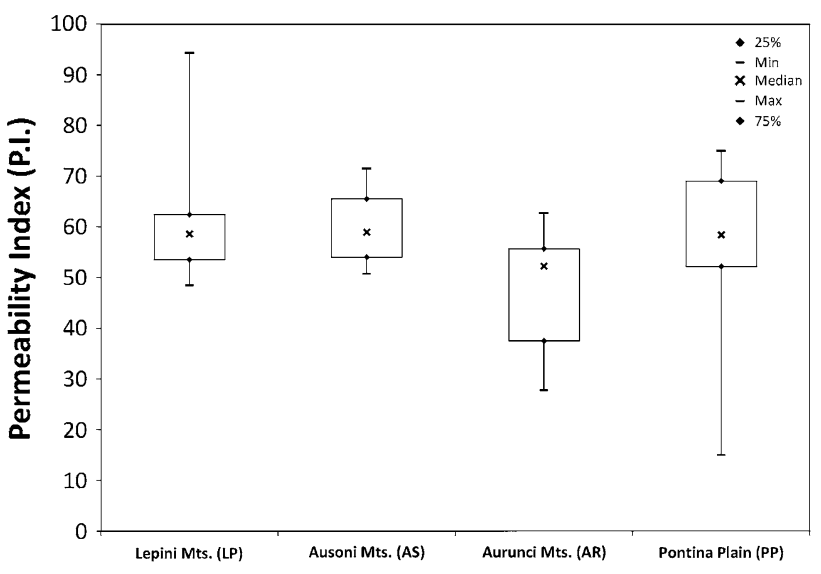

Fig. 8 Box plot of mean, median, maximum and minimum values of permeability index (PI)

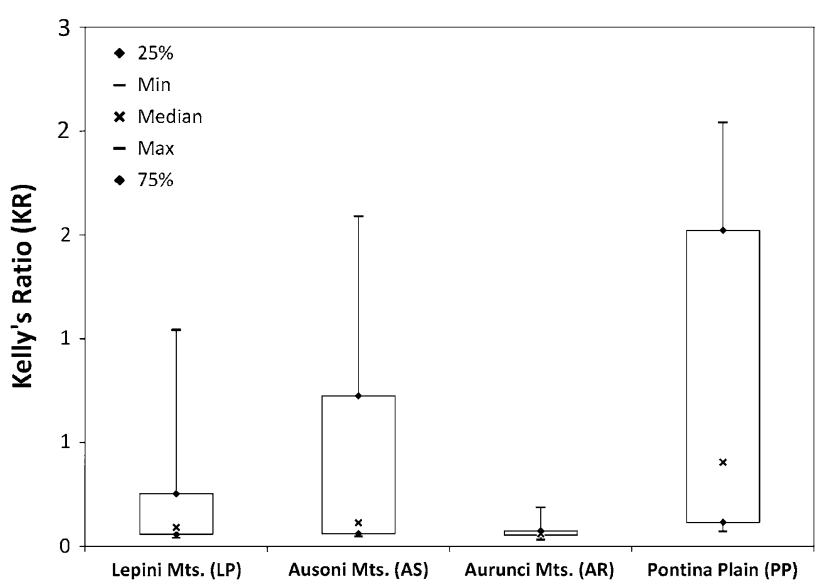

Fig. 9 Box plot of mean, median, maximum and minimum values of Kelly's ratio (KR)

for irrigation purposes (Table 2). However, some groundwater samples from Pontina Plain fall in Class III and classified as unsuitable for irrigation purposes.

Kelly's ratio $(K R)$ Kelly's ratio was calculated employing the following equation:

$\frac{\mathrm{Na}^{+}}{\mathrm{Ca}^{2+}+\mathrm{Mg}^{2+}}$.

Groundwater having Kelley's ratio less than one is generally considered suitable for irrigation (Kelley 1940; Paliwal 1967). Kelly's ratio for water samples varies from 0.03 to 2.04 (Table 2). Most of the water samples ( $~ 82 \%$ ) have $\mathrm{KR}$ value $<1$, highlighting the good quality of groundwater for irrigation purposes (Fig. 9).

$\mathrm{Na} \%$ Sodium percentage is an important parameter for studying sodium hazard. $\mathrm{Na} \%$ is calculated using the 


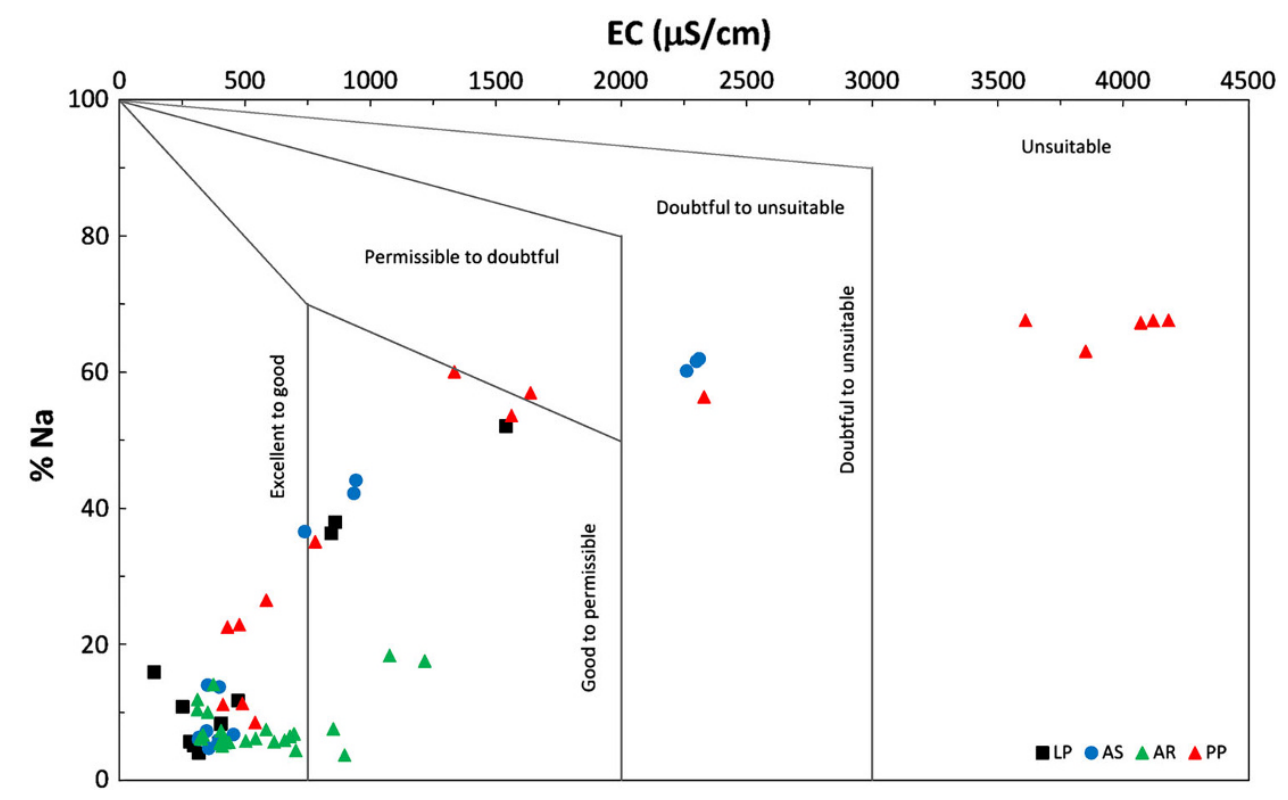

Fig. 10 Plot of per cent sodium versus electrical conductivity (after Wilcox 1955)

following formula (Wilcox 1955) and all concentrations were expressed in meq/l:

$\frac{\mathrm{Na}+\mathrm{K}}{\mathrm{Ca}+\mathrm{Mg}+\mathrm{Na}+\mathrm{K}} \times 100$.

High-percentage sodium water for irrigation purpose reduces soil permeability and may prevent the plant growth (Joshi et al. 2009). The classification of groundwater was grouped based sodium as excellent $(<20 \%)$, good (20-40\%), permissible (40-60\%), doubtful (60-80\%) and unsuitable $(>80 \%)$. The irrigation water classification diagram (Wilcox 1955) was used to assess the water quality (Fig. 10). Water samples were grouped into four categories according to irrigation water assessment with per cent sodium and the results are shown in Table 2. According to Wilcox classification, $69 \%$ of the water samples have excellent irrigation water quality, $12.1 \%$ of the samples have good water quality and $6.8 \%$ of the samples fall in the category of permissible irrigation water. However, $12.1 \%$ of samples which were influenced by seawater were classified as doubtful for irrigation.

\section{Conclusions}

Groundwater and spring waters from carbonate aquifers of southern Latium region, Central Italy, were investigated to evaluate the water quality for drinking and irrigation purposes. The results of hydrochemical analysis show that springs and groundwater in the study area are characterized fresh to brackish and slightly acidic to alkaline in nature.
The types of water that predominates in the study area are (1) $\mathrm{Ca}-\mathrm{Mg}-\mathrm{HCO}_{3}$, (2) mixed facies between $\mathrm{Ca}-\mathrm{HCO}_{3}$ and $\mathrm{Na}-\mathrm{Cl}$, (3) $\mathrm{Na}-\mathrm{Cl}$ and (4) $\mathrm{Ca}-\mathrm{Cl}$. The distribution of major anions and cations and occurrence of different hydrochemical facies suggest that the composition of springs and groundwater are influenced by water-rock interaction and seawater intrusion in coastal area to reach a final stage of evolution represented by the $\mathrm{Na}-\mathrm{Cl}$ water type (i.e. ion exchange interaction). Gibbs diagrams also suggest that water-rock interaction and evaporation are the main mechanisms controlling the water chemistry in the study area. Springs and groundwater samples were classified as hard and very hard water and few samples exceed the allowable limit for domestic uses. According to USsalinity diagram, most of the water samples fall in $\mathrm{C} 2-\mathrm{S} 1$ classes highlighting medium salinity and low sodium content class. However, some spring water (i.e. discharges at lower elevations) and groundwater samples fall in the field of C3-S1 and C4-S2. Most of the groundwater samples from Pontina Plain fall in the category, C3-S2 and C4-S3 showing high to very high salinity and medium to high sodium hazard. Concerning the $\mathrm{Na} \%$ parameter, about $\sim 70 \%$ of spring and groundwater in the study area is classified as excellent to good for irrigation.

The results of physico-chemical analyses (TDS, pH, EC and major ions) and the calculated water quality parameters (SAR, ESR, Mg-hazard and Na-hazard, total hardness, Kelly's ratio, permeability index, sodium percentage) show that most of the water samples in this area was seen to be good and suitable for drinking and irrigation purposes; 
however, some of the groundwater and springs were found to be unsuitable for irrigation in a few places due to seawater intrusion (i.e. high salinity) and enhanced water-rock interaction (based on magnesium hazard). It was concluded that the most of the calculated indices fall within the recommended limits of US-EPA (1986), WHO and USSL; however, the control of sodium and salinity hazard is required for irrigation.

Acknowledgments The authors would like to thank the Regional Basins Authority of Latium for the financial support of the project.

Open Access This article is distributed under the terms of the Creative Commons Attribution License which permits any use, distribution, and reproduction in any medium, provided the original author(s) and the source are credited.

\section{References}

Accordi B, Biasini A, Caputo C, Devoto G, Funiciello R, La Monica GB, Lupia Palmieri E, Matteucci R, Pieruccini U (1976) Geologia e dissesti del territorio montano della Regione Lazio. In: Carta della Montagna, vol 2. Monografia Regionali No. 12 Lazio, Ministero di Agricoltura, Roma, pp 55-101

Adams S, Titus R, Pietersenb K, Tredouxc G, Harris C (2001) Hydrochemical characteristics of aquifers near Sutherland in the Western Karoo. S Afr J Hydrol 241:91-103

Ayers RS, Westcot DW (1994) Water quality for agriculture, irrigation and drainage paper. http://www.fao.org/DOCREP/ 003/T0234E/T0234E00.htm

Bernardi D, Dini FL, Azzarelli A, Giaconi A, Volterrani C, Lunardi M (1995) Sudden cardiac death rate in an area characterized by high incidence of coronary artery disease and low hardness of drinking water. Angiology 46:145-149

Boni C (1975) The relationship between the geology and hydrology of the Latium-Abruzzi Apennines. In: Parotto M, Praturlon A (eds) Geological summary of the central Apennines, Quaderni de "La ricerca scientifica", vol 90. Structural Model of Italy, pp 301-311

Briz-Kishore BH, Murali G (1992) Factor analysis for revealing hydrochemical characteristics of a watershed. Environ Geol 19:3-9

Celico P (1978) Schema idrogeologico dell'Appennino carbonatico centro-meridionale. Memorie e Note dell'Istituto di Geologia Applicata, Napoli 14:1-97

Chen J, Wang Y, Zhang H (2006) Overview on the studies of nitrate pollution in groundwater. Prog Geogr 25(1):34-44

Chenini I, Khmiri S (2009) Evaluation of ground water quality using multiple linear regression and structural equation modelling. Int J Environ Sci Technol 6(3):509-519

Doneen LD (1964) Water quality for agriculture. Department of Irrigation, University of Calfornia, Davis

Edmunds WM, Cook JM, Darling WG, Kinniburgh DG, Miles DL, Bath AH, Morgan-Jones M, Andrews JN (1987) Baseline geochemical conditions in the Chalk aquifer, Berkshire, UK: a basis for groundwater quality management. Appl Geochem 2:251-274

Ettazarini S (2005) Processes of water-rock interaction in the Turonian aquifer of Oum Er-Rabia Basin, Morocco. Environ Geol 49:293-299. doi:10.1007/s00254-005-0088-x
Food and Agriculture Organization (FAO) (1992) The use of saline waters for crop production. Irrigation and drainage paper 48 . FAO, Rome

Gibbs RJ (1970) Mechanisms controlling world water chemistry. Science 170:1088-1090

Jain CK, Bandyopadhyay A, Bhadra A (2009) Assessment of ground water quality for drinking purpose, District Nainital, Uttarakhand, India. Environ Monit Assess Springer 166:663-676. doi:10.1007/s10661-009-1031-5

Joshi DM, Kumar A, Agrawal N (2009) Assessment of the irrigation water quality of River Ganga in Haridwar District India. J Chem 2(2):285-292

Kelley WP (1940) Permissible composition and concentration of irrigation water. Proc Am Soc Civ Eng 66:607-613

Kirda C (1997) Assessment of irrigation water quality. Options Mediterr 31:367-377

Kumar K, Rammohan SV, Dajkumar Sahayam J, Jeevanandam M (2009) Assessment of groundwater quality and hydrogeochemistry of Manimuktha River basin, Tamil Nadu, India. Environ Monit Assess 159:341-351. doi:10.1007/s10661-008-0633-7

US Salinity Laboratory (1954) Diagnosis and improvement of saline and alkali soils, Department of Agriculture, U.S. Handbook 60, Washington DC

Mahler BJ, Massei N (2007) Anthropogenic contaminants as tracers in an urbanizing karst aquifer. J Contam Hydrol 91:81-106

Mayer J (1999) Spatial and Temporal Variation of Groundwater Chemistry in Pettyjohns Cave, Northwest Georgia, USA. J Cave Karst Stud 61(3):131-138

Memon M, Soomro MS, Akhtar MS, Memon KS (2011) Drinking water quality assessment in Southern Sindh (Pakistan). Environ Monit Assess 177:39-50. doi:10.1007/s10661-010-1616-Z

Mercado A, Billings GK (1975) The kinetics of mineral dissolution in carbonate aquifers as a tool for hydrological investigations, I. Concentration-time relationships. J Hydrol 24:303-331

Moral F, Cruz-Sanjulián JJ, Olías M (2008) Geochemical evolution of groundwater in the carbonate aquifers of Sierra de Segura (Betic Cordillera, southern Spain). J Hydrol 360:281-296

Paliwal KV (1967) Effect of gypsum application on the quality of irrigation waters. Madras Agric J 59:646-647

Palma P, Alvarenga P, Palma VL, Fernandes RM, Soares AMVM, Barbosa IR (2010) Assessment of anthropogenic sources of water pollution using multivariate statistical techniques: a case study of Alqueva's reservoir, Portugal. Environ Monit Assess 165:539-552

Richards LA (1954) Diagnosis and improvement of saline and alkali soils. Agricultural handbook 60. USDA and IBH Pub. Coy Ltd., New Delhi, pp 98-99

Rizwan R, Singh G (2009) Physico-chemical analysis of groundwater in Angul-Talcher region of Orissa, India. J Am Sci 5(5):53-58

Rockware AqQA Software (2011) Version AQC10664. http://www. rockware.com

Saleh A, Al-Ruwaih F, Shehata M (1999) Hydrogeochemical processes operating within the main aquifers of Kuwait. J Arid Environ 42:195-209

Sappa G, Barbieri M, Ergul S, Ferranti F (2012) Hydrogeological conceptual model of groundwater from carbonate aquifers using environmental isotopes $\left({ }^{18} \mathrm{O},{ }^{2} \mathrm{H}\right)$ and chemical tracers: a case study in southern Latium region, Central Italy. J Water Resour Prot (JWARP) 4(9). doi:10.4236/jwarp.2012.49080

Shaki A, Adeloye A (2006) Evaluation of quantity and quality of irrigation water at Gadowa irrigation project in Murzuq Basin, southwest Libya. Agric Water Manag 84:193-201

Singh K, Malik A, Mohan D, Sinha S (2004) Multivariate statistical techniques for the evaluation of spatial and temporal variations in water quality of Gomti River (India) - a case study. Water Res 38(18):3980-3992

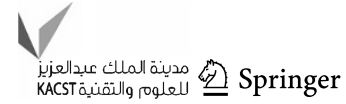


Singh AK, Mondal GC, Kumar S, Singh TB, Tewary BK, Sinha A (2008) Major ion chemistry, weathering processes and water quality assessment in upper catchment of Damodar River basin, India. Environ Geol 54:745-758

Szabolcs I, Darab C (1964) The influence of irrigation water of high sodium carbonate content of soils. In: Proceedings of 8th international congress of ISSS, transmission, vol 2. pp 803-812

Ternan JL (1972) Comments on the use of a calcium hardness variability index in the study of carbonate aquifers: with reference to the central Pennines, England. J Hydrol 16:317-321

US Environmental Protection Agency (1986) Quality criteria for water 1986. EPA 440/5-86-001. Washington, DC 20460
Van der Hoek W, Konradsen F, Ensink JHJ, Mudasser M, Jensen PK (2001) Irrigation water as a source of drinking water: is safe use possible? Trop Med Int Health 6(1):46-54

White WB (1988) Geomorphology and hydrology of karst terrains. Oxford University Press, New York, p 464

WHO (2004) Guidelines for drinking water quality (3rd edn). Recommendations, vol 1. World Health Organization, Geneva

WHO (2006) Guideline for drinking water quality. Vol. recommendations. World Health Organization, Geneva, p 130

Wilcox LV (1955) Classification and use of irrigation waters. USDA Circ. 969, Washington, DC 